\title{
PERAN BADAN PERMUSYAWARATAN DESA DALAM PENYELENGGARAAN PEMERINTAHAN DESA
}

\author{
Sofian Malik \\ Fakultas Hukum, Universitas Iqra Buru, Kab.Buru, Maluku. \\ sofyanmalik123@gmail.com
}

\begin{abstract}
Abstrak
Penelitian ini berujuan untuk mengkaji peran Badan Permusyawaratan Desa (BPD) terhadap pemerintahan desa dan faktor-faktor apa yang menghambat peran Badan Permusyawaratan Desa (BPD) terhadap pemerintahan desa di Desa Labuang. Keberadaan Badan Permusyawaratan Desa (BPD) dalam pemerintahan desa adalah bukti keterlibatan masyarakat. Hal ini sejalan dengan tujuan utama pembentukan lembaga badan permusyawaratan desa yang disingkat BPD yang pada dasarnya adalah penjelmaan dari segenap warga masyarakat dan merupakan lembaga tinggi desa yang mampu memeperhatikan kepentingan masyarakat di sebuah wilayah khususnya pada sebua desa. Penelitian ini adalah tipe penelitian deskripitif yaitu suatu penelitian yang menggambarkan fenomena-fenomena tentang suatu tata laksana kerjasama BPD dengan Kepala desa, dengan demikian pendekatan yang digunakan adalah pendekatan normatif. Hasil penelitian menunjukkan bahwa BPD di Desa Labuang Kecamatan Namrole Kabupaten Buru Selatan belum dapat menjalankan perannya secara optimal disebabkan sumber daya manusia anggota BPD masih rendah, khususnya dalam bidang pendidikan sehingga dalam menjalankan peran dan fungsinya BPD tidak mengerti apa yang harus dilakukan terkait dengan fungsi kontrol dan fungsi pengawasan yang menjadi kewenangannya dalam mengontrol dan mengawasi kinerja pemerintah desa/kepala desa, anggaran operasional BPD sangat minim serta sarana dan prasarana BPD sangat tidak memadai dan tidak memiliki kantor sendiri sehingga dalam menjalankan tugasnya, anggota BPD yang tidak secara aktif mensosialisasikan sebuah peraturan desa.
\end{abstract}

Kata kunci: Pemerintahan; Lembaga Desa; Kontrol 
THE ROLE OF THE VILLAGE CONSULTANTS AGENCY IN THE IMPLEMENTATION OF VILLAGE GOVERNMENT

\author{
Sofian Malik \\ Fakultas Hukum, Universitas Iqra Buru, Kab.Buru, Maluku \\ sofyanmalik123@gmail.com
}

\begin{abstract}
This study aims to examine the role of the Village Consultative Body $(B P D)$ on village governance and what factors are hampering the role of the Village Consultative Body (BPD) on village governance in Labuang Village. The existence of the Village Consultative Body (BPD) in the village administration is evidence of community involvement. This is in line with the main objective of establishing a village consultative body, abbreviated as BPD, which is basically the embodiment of all members of the community and is a high-ranking village institution capable of paying attention to the interests of the community in an area, especially in an entire village. This research is a type of descriptive research that is a study that describes the phenomena about the governance of BPD collaboration with the village head, thus the approach used is a normative approach. The results showed that BPD in Labuang Village, Namrole Subdistrict, South Buru Regency had not been able to carry out their roles optimally due to the low human resources of $B P D$ members, especially in the field of education so that in carrying out their roles and functions the BPD did not understand what to do related to the control function and the supervisory function which is its authority in controlling and overseeing the performance of the village government / village head, BPD operational budget is very minimal and BPD facilities and infrastructure are inadequate and do not have their own office so that in carrying out their duties, BPD members who do not actively socialize a village regulation.
\end{abstract}

Keywords: Governance; Village Institutions; Control 


\section{PENDAHULUAN}

\section{A. Latar Belakang}

Otonomi daerah telah memberikan ruang gerak bagi partisipasi masyarakat dalam pembangunan, yang menjadikan masyarakat tidak hanya sebagai objek pembangunan tetapi juga sebagai subjek pembangunan dan dengan tingkat partisipasi tersebut diharapkan akselerasi hasil-hasil pembangunan dapat segera diwujudkan dan berdayaguna dalam peningkatan kualitas kehidupan masyarakat ${ }^{1}$. Partisipasi masyarakat tersebut di samping dilaksanakan oleh lembaga-lembaga non formal seperti keterlibatan Lembaga Swadaya Masyarakat (LSM), kelompok-kelompok kepentingan lain melalui tuntutan-tuntutan terhadap pemerintah atau bentuk penolakan terhadap kebijakan pemerintah, juga dilaksanakan oleh lembaga-lembaga formal pada tingkat daerah melalui kewenangan lebih besar pada Dewan Perwakilan Rakyat Daerah (DPRD) dan di tingkat desa dengan pembentukan Badan Permusyawaratan Desa (BPD). ${ }^{2}$

Terbentuknya Badan Permusyawaratan Desa (BPD) bertujuan untuk mendorong tercipatanya partnership yang yang harmonis serta tidak konfrontatif antara kepala desa pemerintah desa, dan BPD sebagai wakil-wakil rakyat desa yang diperagakan oleh lembaga legislatif baik ditingkat kabupaten/kota provinsi dan pusat. Pelaksanaan Fungsi Badan Permusyawaratan Desa (BPD) dalam Penyelenggaraan Pemerintahan Desa

1 Ahadi Fajrin Prasetya, Peran Badan Permusyawaratan Desa dalam Mewujudkan Pembentukan Peraturan Desa yang Partisipatif di Kabupaten Lampung Timur. Fiat Justisia, Vol. 10 No 3, 2016, Universitas Bandar Lampung, Lampung, hal 415. https://doi.org/10.25041/fiatjustisia.v10no3.785

${ }^{2}$ Susiati, S., Iye, R., \& Suherman, L. O. A. Hot Potatoes Multimedia Applications in Evaluation of Indonesian Learning in SMP Students in Buru District. ELS Journal on Interdisciplinary Studies in Humanities, Vol. 2 No 4, 2019, Universitas Hasanuddin Makassar, Makassar, hal, 558. 
(suatu studi di Desa Bolangitang Satu Kecamatan Bolangitang Barat Kabupaten Bolaang Mongondow. Penelitian ini terkait dengan penelitian yang di angkat oleh Rico Masuara ${ }^{3}$. Persamaan dan perbedaan dengan penulisan artikel ini, yakni sama-sama mengangkat topik mengenai peran Badan Permusayawaratan Desa sebagai objek kajian penelitian namun pada penelitian Rico. Objek yang dikaji mengenai fungsi sedangkan pada penulisan artikel ini yang yang diangkat adalah aspek aturanya dengan menggunakan metode normatif.

Penelitian yang terkait dengan Badan Permusyawaratan Desa juga dilakukan oleh Susanti dan Setiadji (2018), penelitian tersebut lebih membahas mengenai penguatan peran Badan Permusyawaratan Desa (BPD) dalam mendukung sinergitas penyelenggaraan pemerintahan desa di Kabupaten Semarang Tahun 2018. ${ }^{4}$ Penelitian tersebut bertujuan untuk memberikan pemahaman pergeseran kedudukan BPD pasca berlakunya Undang-undang Nomor 6 Tahun 2014 tentang desa, dan meningkatkan pemahaman anggota BPD se-Kabupaten Semarang agar memahami dan menyadari peran, fungsi, tugas, serta kewenangannya, serta model penguatan peran BPD dalam mendukung sinergitas penyelenggaraan pemerintahan desa di Kabupaten Semarang tahun 2018. Penelitian Susanti dan Setiaji tersebut memiliki persamaan dengan penelitian ini yakni BPD menjadi objek kajian serta memberikan tawaran kepada masyarakat dan pemerintah desa mengenai fungsi dan peranya. Adapaun perbedaannya yakni pada penulisan artikel ini yang dianalisis mengenai peran Badan Permusayawaratan Desa dan faktornya.

3 Masuara Rico, Pelaksanaan Fungsi Badan Permusyawaratan Desa (BPD) dalam Penyelenggaraan Pemerintahan Desa (Suatu Studi di Desa Bolangitang Satu Kecamatan Bolangitang Barat Kabupaten Bolaang Mongondow Utara), Jurnal POLITICO, Jurnal Ilmu Politik, Vol. 3 No 1, 2014, Universitas Sam Ratulangi Manado, Manado, hal 4.

4 Susanti. \& Setiaji, "Penguatan Peran Badan Permusyawaratan Desa (BPD) dalam Mendukung Sinergitas Penyelenggaraan Pemerintahan Desa Di Kabupaten Semarang Tahun 2018. INTEGRALISTIK. Journal UNNES., Vol. 29 No 2, 2018, Universitas Negeri Semaranag, Semarang, hal 8. http://dx.doi.org/10.15294/integralistik.v29i2.17947 
Sedangkan penelitian yang dilakukan oleh Darmini Roza dan Laurensius Arliman S (2017) membahas tentang bagaimana peran vital BPD sebagai penerus aspirasi masyarakat di dalam pemerintahan desa. Dalam penelitian tersebut juga menjelasankan tentang fungsi pengawasan BPD terhadap kebijakan kepala desa dan pengawasan keungan desa. Peran serta dari masyarakat juga memengang peranan penting terhadap keberhasilan BPD dalam melkasanakan tugas dan funsinya secara optimal ${ }^{5}$.

Berdasarkan UU Nomor 9 Tahun 2015 Badan Permusyawaratan Desa dikatakan melaksanakan perannya apabila telah ikut dalam pembuatan kebijakan desa dan menampung aspirasi masyarakat ${ }^{6}$. Sementara itu dari sisi masyarakat, poin penting yang dirasakan di dalam era otonomi daerah adalah semakin transparannya pengelolaan pemerintah desa dan semakin pendeknya rantai birokrasi, dimana hal tersebut secara langsung maupun tidak langsung berpengaruh positif terhadap jalannya pembangunan desa. ${ }^{7}$

Keberadaan Badan Permusyawaratan Desa (BPD) dalam pemerintahan desa adalah bukti keterlibatan masyarakat tersebut ${ }^{8}$. Hal ini sejalan dengan tujuan utama pembentukan Lembaga Badan Permusyawaratan Desa yang disingkat BPD yang pada dasarnya adalah penjelmaan dari segenap warga masyarakat dan merupakan lembaga tinggi Desa. BPD juga merupakan pemegang dan pelaksana sepenuhnya kedaulatan masyarakat desa. Lembaga ini memiliki urgensi yang tidak jauh

${ }^{5}$ Darmini Roza, Laurensius Arliman S. "Peran Badan Permusyawaratan Desa (BPD) dalam Pembangunan Desa dan Pengawasan Keuangan Desa" PJIH: Jurnal Padjajaran Ilmu Hukum, Vol. 4 No 3. 2017, Universitas Padjajaran, Bandung, hal 11. DOI: https://doi.org/10.22304/pjih.v4n3.a10

${ }^{6}$ Rodhiah \& Harir, Peranan Badan Permusyawaratan Desa (BPD) Dalam Pembentukan Peraturan Desa Di Desa Krandon Kecamatan Guntur Kabupaten Demak. Jurnal Pembaharuan Hukum, Vol. 2 No 2. 2015, Universitas Islam Sultan Agung Semarang, Semarang, hal, 298. http://dx.doi.org/10.26532/jph.v3i3.1375

7 Ngarsiningtyas dan Walid, "Peran Badan Permusyawaratan Desa dalam Penyusunan dan Penetapan Peraturan Desa" JPPUMA: Jurnal Ilmu Pemerintahan dan Sosial Politik UMA, Vol. 4 No 2. 2016, Universitas Medan Area, Medan, hal 170. http://dx.doi.org/10.31289/jppuma.v4i2.454

${ }^{8}$ Sam, B., Iye, R., Ohoibor, M., Umanailo, M. C. B., Rusdi, M., Rahman, A. B. D., \& Hajar, I. Female Feminism in the Customary Island of Buru. Int. J. Sci. Technol. Res, Vol. 8 No 8, 2019, International Journal of Scientific \& Technology Research, New Delhi, hal 220. 
berbeda dengan DPR. Karenanya agar otonomi di desa dapat berjalan secara proporsional.

Perbedaan penelitian ini dibandingkan dengan penelitian sebelumnya dapat dilihat dari penelitian yang dilakukan oleh Rico Masuara mengakaji tentang peran dan fungsi BPD, sedangkan penelitian yang dilakukan oleh Susanti dan Setiadji megkaji tentang penguatan BPD sebagai lembaga desa yang mengawasi pembangunan dan penyelenggaraan pemerintahan di desa. Penelitian tersebut juga hampir mirip dengan penelitian yang dilakukan oleh Darmini Roza dan Laurensius Arliman S yang mengkaji tentang tugas dan fungsi BPD dalam melakukan pengawasan terhadap kebijakan kepala desa dan pengawasan keuangan desa. Penelitian ini melengkapi penelitian tentang BPD sebelumnya. Penelitian ini lebih fokus mengkaji mengenai aspek pengaturan dan peran BPD dalam pemerintahan desa dan faktor faktor yang menghambat efektifitas kinerja BPD dalam menjalankan tugas dan fungsinya. Penelitian ini berujuan untuk mengkaji peran Badan Permusyawaratan Desa (BPD) terhadap pemerintahan desa dan faktor-faktor apa yang menghambat peran Badan Permusyawaratan Desa (BPD) terhadap pemerintahan desa di Desa Labuang

\section{B. Perumusan Masalah}

Berdasarkan latar belakang di atas maka adapun rumusan masalah dalam penelitian ini yakni:

1. Bagaimanakah peran Badan Permusyawaratan Desa (BPD) terhadap pemerintahan desa?

2. Faktor-faktor apa yang menghambat peran Badan Permusyawaratan Desa (BPD) terhadap pemerintahan desa di Desa Labuang ?

\section{Landasan Teoritis}

Penelitian ini adalah tipe penelitian deskripitif yaitu suatu penelitian yang menggambarkan fenomena-fenomena tentang suatu tata laksana kerjasama BPD dengan Kepala desa, dengan demikian pendekatan yang digunakan adalah pendekatan normatif. Adapun lokasi penelitian ini yakni di Desa Labuang Kecamatan Namrole. Kabupaten Buru. 
Penelitian ini penulis menggunakan Bahan hukum yaitu; (a) Bahan hukum primer (Primary Source or Authorilies) yakni berupa Undang-Undang Dasar Negara Republik Indonesia Tahun 1945, Undang Undang Otonomi Daerah serta peraturan perundang-undangan lainnya yang menyangkut, tentang Pemerintahan Desa dan Badan Permusyawaratn Desa dan (b) Bahan hukum sekunder (Secondary source or Authorities) yakni berupa literatur (buku-buku ilmiah) hukum yang resmi diterbitkan, makalah, jurnal, majalah dan surat kabar sepanjang berkaitan dengan objek ini.

Teknik pengumpulan data yaitu dengan menginventarisir peraturan Perundang-undangan untuk dipelajari sebagai suatu kesatuan yang utuh dan dengan studi kepustakaan, internet browsing, telah artikel ilmiah, telaah karya ilmiah sarjana dan studi dokumen, termasuk di dalamnya karya tulis ilmiah maupun jurnal surat kabar. Metode pengumpulan data menggunakan studi kepustakaan yaitu teknik mengumpulkan data dengan cara membaca dan mempelajari buku-buku kepustakaan yang berkaitan dengan materi penelitian, kemudian menyusun sebagai sajian data. Metode dokumentasi adalah salah satu cara pengumpulan data yang digunakan penulis dengan cara menelaah dokumen-dokumen pemerintah maupun non pemerintah yang berkaitan dengan penelitian ini. Instrument yang digunakan berupa form dokumentasi, form kepustakaan, dan alat-alat perpustakaan lainnya.

Setelah bahan hukum sekunder dan primer yang diperoleh diolah dan dianalisis secara kuantitatif untuk menghasilkan bahan-bahan deskriptif, berupa bahan-bahan yang relevan dengan objek penelitian. Adapun pendekatan yang digunakan dalam penelitian ini adalah pendekatan hukum normatif.

\section{PEMBAHASAN}

\section{A.Peran Badan Permusyawaratan Desa (BPD) Terhadap Pemerintahan Desa}

Perkembangan politik di Indonesia yang terus berkembang dari orde lama sampai sekarang. Kebijakan politik maupun pemerintahan orde lama lebih menekankan sikap sentralisasi, dimana semua 
urusan diserahkan sepenuhnya kepusat. Hal ini tentunya belum terdapat adanya otonomi daerah, baik di tingkat desa sampai tingkat provinsi. Masing-masing daerah sepenuhnya disetir oleh pemerintah, pada tingkat desa misalnya, kebijakan-kebijakan pemerintah melalui perangkat desa merupakan kebijakan atasannya dari camat, bupati, gubernur, sampai ke pusat, sehingga perangkat desa belum memaksimalkan keadaan desa yang dipimpinnya ${ }^{9}$.

Desa dan Badan Permusayawatan Desa (BPD) wajib menjalankan tugasnya dengan penuh rasa tanggungjawab karena jabatan sebagai pemerintah merupakan amanah dari rakyat, sehingga aspirasi masyarakat yang dipimpinya dapat terlakasana dengan baik melalui program yang nayata untuk digunakan untuk kepentingan masyarakat. Saat ini, upaya untuk membangun dan mengembangkan kehidupan masyarakat desa dirasakan semakin penting. Hal ini disebabkan disamping karena sebagian besar penduduk tinggal di pedesaan, kini partisip asi masyarakat di dalam kegiatan pembangunan juga sangat diharapkan, sebagaimana tercantum dalam Undang-Undang Nomor 9 Tahun 2015 tentang pemerintahan daerah ${ }^{10}$. Otonomi daerah sangat mensyaratkan keadaan sumber daya manusia yang mumpuni, karena mereka inilah yang kelak akan lebih banyak menentukan bergerak atau tidaknya suatu daerah di dalam menjalankan kegiatan pembangunan dan pemerintahan pada umumnya.

Seiring dengan reformasi total mulai tahun 1998 di semua bidang yang sekarang dilakukan adalah berasal dari niat dan komitmen seluruh kekuatan rakyat untuk tetap percaya bahwa Undang-Undang Dasar 1945 sebagai konstitusi. Selain itu juga dituntut kemampuan seluruh lembaga negara, lembaga pemerintahan, dan rakyat, untuk

\footnotetext{
9 Susanti dan Setiaji, 2018. Op cit, hal 2.

10 Bachsan Mustafa, Sketsa Dari Tata Hukum Indonesia, CV Amriko, 1982, Bandung, hal 12
} 
melaksanakan ketentuan-ketentuan konstitusi itu secara tepat dan kesediaan semua pihak untuk menjalankannya. Munculnya Undang-undang No. No. 9 Tahun 2015 tentang Pemerintahan Daerah (otonomi), Peraturan Pemerintah No. 6 Tahun 2014 tentang Desa.

Peraturan menteri dalam Negeri No 110 Tahun 2016 dan Peraturan Daerah Kabupaten Buru Selatan No. 24 Tahun 2011 tentang Badan Permusyawaratan Desa dipandang sebagai bagian dari proses besar demokratisasi. Suatu otonomi bukan final, melainkan langkah awal $^{11}$. Dengan demikian isi dan realisasi isi dari otonomi menjadi sangat penting. Peralihan Indonesia menuju demokrasi dari pemerintahan otoriter menjadi peristiwa politik paling dramatis pada akhir abad ke-20. ${ }^{12}$ Meski kadang-kadang menyakitkan, transisi telah mengembalikan Indonesia kepada kebebasan yang sudah tak terlihat di negeri ini sejak eksperimen demokrasi yang berusia pendek pada 1950-an. Kelahiran kebijakan pemerintah khususnya Undang-undang No. 9 Tahun 2015 mengenai Pemerintah Daerah ini membawa sebuah harapan baru bagi perjalanan bangsa ini ke masa depan yang lebih baik.

Hal ini sangatlah wajar karena kebijakan sebelumnya yang nota bene melahirkan sebuah kenyataan politis yakni adanya sentralisasi di hampir segala bidang telah membawa dampak yang begitu besar dengan multi krisis sebagai akhir episode sebuah rezim. Kenyataan masa lalu memberitahu kepada kita semua satu hal namun berimplikasi pada sebuah multiplier effect yakni adanya kooptasi penguasa yang begitu membelenggu baik dari tingkat desa, desa sampai kepada individu-individu rakyat dalam masyarakat. Karena itu, Pasal 18

${ }^{11}$ Tahir Azhari, Muhammad. Negara Hukum, Prenada Media, 2004. Jakarta hal 13.

12 Saldi Isra. Pergeseran Fungsi Legislasi : Menguatnya Model Legislasi Parlementer Dalam Sistem Presidensial Indonesia. Raja Grafindo Persada, 2010. Jakarta, hal 24. 
Undang-undang Dasar 1945 antara lain menyatakan bahwa pembagian daerah Indonesia atas daerah besar dan kecil, dengan bentuk dan susunan pemerintahannya ditetapkan dengan undang-undang.

Undang-undang Dasar Negara Republik Indonesia Tahun 1945 mengamanatkan bahwa pemerintah daerah berwenang untuk mengatur dan mengurus sendiri urusan pemerintahan menurut asas otonomi dan tugas pembantuan. Pemberian otonomi luas kepada daerah diarahkan untuk mempercepat terwujudnya kesejahteraan masyarakat melalui peningkatan pelayanan, pemberdayaan, dan peran serta masyarakat. Di samping itu melalui otonomi luas, daerah diharapkan mampu meningkatkan daya saing dengan memperhatikan prinsip demokrasi, pemerataan, keadilan, keistimewaan dan kekhususan serta potensi dan keanekaragaman daerah dalam Sistem Negara Kesatuan Republik Indonesia (NKRI).

Jiwa otonomi daerah sebenarnya adalah untuk membangun kemandirian daerah itu sendiri sekaligus meningkatkan kualitas demokrasi di tingkat lokal. Kinerja demokrasi dapat diukur melalui sejauh mana produk kebijakan-kebijakan yang ada dapat menumbuhkan prakarsa masyarakat dan bukan sebuah ketergantungan. Penting disadari bahwa dalam kebijakan otonomi daerah, termuat pula segi mendasar yakni otonomi daerah yang bisa dikatakan sebagai saripati dari otonomi daerah.

Otonomi daerah telah memberikan ruang gerak bagi partisipasi masyarakat dalam pembangunan, yang menjadikan masyarakat tidak hanya sebagai objek pembangunan tetapi juga sebagai subjek pembangunan dan dengan tingkat partisipasi tersebut diharapkan akselerasi hasil-hasil pembangunan dapat segera diwujudkan dan berdayaguna dalam peningkatan kualitas kehidupan 


$$
\begin{array}{llccr}
\text { masyarakat }^{13} \text {. } & \text { Partisipasi } & \text { masyarakat } & \text { tersebut di } & \text { samping } \\
\text { dilaksanakan } & \text { oleh lembaga-lembaga } & \text { non formal } & \text { seperti } \\
\text { keterlibatan } & \text { Lembaga } & \text { Swadaya } & \text { Masyarakat } & \text { (LSM), }
\end{array}
$$

kelompok-kelompok kepentingan lain melalui tuntutan-tuntutan terhadap pemerintah atau bentuk penolakan terhadap kebijakan pemerintah, juga dilaksanakan oleh lembaga-lembaga formal pada tingkat daerah melalui kewenangan lebih besar pada Dewan Perwakilan Rakyat Daerah (DPRD) dan di tingkat desa dengan pembentukan Badan Permusyawaratan Desa (BPD). ${ }^{14}$

Prinsip otonomi daerah menggunakan prinsip otonomi seluas-luasnya dalam arti daerah diberikan kewenangan mengurus dan mengatur semua urusan pemerintahan di luar yang menjadi urusan pemerintah yang ditetapkan dalam undang-undang. Daerah memiliki kewenangan membuat kebijakan daerah untuk memberi pelayanan, peningkatan peran serta, prakarsa, dan pemberdayaan masyarakat yang bertujuan pada peningkatan kesejahteraan rakyat. Sebagai perwujudan demokrasi, di desa dibentuk Badan Permusyawaratan Desa (BPD) yang dulunya Lembaga Musyawarah Desa (LMD) yang berfungsi menetapkan peraturan desa bersama kepala desa, menampung dan menyalurkan aspirasi masyarakat. Anggota Badan Permusyawaratan Desa adalah wakil dari penduduk desa bersangkutan yang ditetapkan dengan cara musyawarah dan mufakat. Pemerintahan daerah dan pemerintah desa telah beralih dari sistem pemerintahan yang sentralistik menjadi desentralistik sehingga pemberian pelayanan kepada publik menjadi lebih dekat dan dapat dilakukan secara optimal. Penerapan ini membawa banyak harapan kepada perbaikan, dalam hal pengelolaan dan

13 Op.Cit, Ahadi Fajrin Prasetya, hal 415.

${ }^{14}$ Susiati, S., Iye, R., \& Suherman, L. O. A. Hot Potatoes Multimedia Applications in Evaluation of Indonesian Learning in SMP Students in Buru District. ELS Journal on Interdisciplinary Studies in Humanities, Vol. 2 No 4, 2019, Universitas Hasanuddin Makassar, Makassar, hal, 558. http://doi.org/10.34050/els-jish.v2i4.8455 
kualitas kinerja daerah. kepala desa dalam hal ini bertanggung jawab kepada Badan Permusyawaratan Desa (BPD) dan menyampaikan laporan pelaksanaan tersebut kepada bupati ${ }^{15}$.

Struktur Badan Permusyawaratan Desa (BPD) merupakan mitra kepala desa dalam memberdayakan masyarakat desa yang anggotanya terdiri dari tokoh masyarakat, RT, RW yang dipilih oleh rakyat. Kepala desa dan perangkat desa tidak boleh menjadi anggota maupun ketua BPD, sehingga kepala desa tidak mempunyai peran penting bahkan kades diawasi oleh BPD. Sedangkan LMD seperti di jelaskan dalam Undang-Undang No. 6 tahun 2015 dan Peraturan Menteri Dalam Negeri No. 110 tahun 2016 yang mengatur tentang LMD dimana pengurus LMD terdiri dari perangkat desa tokoh masyarakat dan ketuanya adalah kepala desa sehingga tampak kepala desa mempunyai peranan penting di desa atau otonom. ${ }^{16}$

Melalui informasi yang didapatkan pada penulisan artikel ini diketahui bahwa masih banyak masyarakat yang tidak mengetahui apa itu Badan Permusyawaratan Desa (BPD), padahal mereka adalah lembaga yang berperan dalam menampung dan menyampaikan aspirasi masyarakat bahkan masyarakat lebih mengenal kepala dusun sebagai perwakilan mereka di desa dan bukan BPD. Selain itu dalam melaksanakan perannya, BPD Desa Labuang tidak memiliki kantor tersendiri, melainkan masih menumpang pada kantor kepala desa. Untuk melakukan pertemuan antar anggota BPD juga dilakukan dalam kantor kepala desa, hal ini menyebabkan kurangnya kebebasan BPD untuk terlepas dari intervensi pihak yang terkait dengan

15 Tegar,"Peran Badan Permusyawaratan Desa Dalam Penyelenggaraan Pemerintahan Desa (Studi Kasus Di Desa Sidodadi Kecamatan Taman Kabupaten Sidoarjo), Publica: Jurnal Ilmu Administrasi Negara, Vol. 4 No 8, 2016, Universitas Negeri Semarang, Semarang, hal 3.

16 Kursahandjani, Implikasi UU No. 6 Tahun 2014 tentang Desa terhadap Penyelenggaraan Pemerintahan Desa. Jurnal Ilmiah Ilmu Pemerintahan, Vol. 2 No 1, 2016, Jurusan Ilmu Pemerintahan Fakultas Ilmu Sosial dan Ilmu Politik, Universitas Diponegoro, Semarang, hal 7. https://dx.doi.org/10.14710/jiip.v2i1.1635 
kinerja BPD. Keadaan seperti itu tentunya akan sulit bagi BPD dalam mengoptimalkan apa yang menjadi perannya sebagai lembaga yang ikut dalam pembuatan peraturan desa.

Namun apakah Badan Permusyawaratan Desa yang dibentuk tersebut dalam realisasinya sudah dapat mengontrol pemerintah desa dan sebaliknya apakah pemerintah desa dengan sistem pemerintahan yang baru ini juga sudah siap untuk dikontrol oleh rakyat melalui badan tersebut. Partisipasi rakyat melalui Badan Permusyawaratan Desa (BPD) ini akan terlihat, karena lewat Badan Permusyawaratan Desa ini masyarakat dapat ikut menentukan kebijakan dalam penyelenggaraan pemerintahan desanya dengan fungsi legislasi dan kontrol yang dimiliki. Bertolak dari pertanyaan sederhana tersebut, mari kita mencoba melihat secara jelas hasil penelitian penulis terkait dengan peran Badan Permusyawaratan Desa (BPD) di Desa Labuang Kecamatan Namrole Kabupaten Buru Selatan. Telah kita ketahui bersama bahwa peran utama BPD adalah bersama kepala desa membuat peraturan desa, menampung dan menyalurkan aspirasi masyarakat di samping itu BPD juga berfungsi sebagai legislator dan kontrol serta pengawas terhadap kinerja pemerintah desa.

Namun fakta di lapangan lembaga Badan Permusyawaratan Desa (BPD) Desa Labuang tidak melaksanakan peran dan fungsinya dengan baik bahkan BPD terkesan melakukan kerja sama dengan pemerintah desa dalam melakukan penyalahgunaan wewenang. Hal ini terungkap dalam wawancara yang dilakukan oleh dengan Bapak Hendrik Tasane selaku sekretaris BPD Desa Labuang, yang menuturkan bahwa Pemerintah Desa Labuang dalam menjalankan tugas dan fungsinya tidak ada masalah.

Menurut penuturan salah seorang tokoh masyarakat di Desa Labuang Bapak Edison Nurlatu, melalui wawancaranya menjelaskan bahwa BPD tidak menjalankan tugas dan fungsinya dengan baik, tidak pernah membuat 
rapat dan tidak mengindahkan atau menyalurkan aspirasi masyarakat, ada kesan seolah-olah adanya kerja sama pemerintah desa Labuang dengan BPD, kurang berfungsinya kantor desa dalam menunjang pemerintahan sehari-hari. Dengan menganalisa problem tersebut di atas, maka penulis menyimpulkan bahwa Lembaga Badan Permusyawaratan Desa (BPD) Desa Labuang Kecamatan Namrole Kabupaten Buru Selatan telah gagal mengemban amanah sebagai legislator desa khususnya dalam program pemberdayaan masyarakat melalui program pembangunan desa. Padahal sebenarrnya kalau kita maknai secara baik, BPD mempunyai posisi yang strategis dalam hal program pembangunan desa.

\section{B. Faktor Penghambat Efektivitas Kinerja Badan Pemusyawaratan Desa}

Daerah yang otonom sangat mensyaratkan keberadaan masyarakat yang otonom pula. Masyarakat yang otonom adalah masyarakat yang berdaya, yang antara lain ditandai dengan besarnya partisipasi mereka di dalam kegiatan pembangunan. Karena itulah, dalam era otonomi daerah yang kini mulai dilaksanakan, peningkatan partisipasi masyarakat dalam kegiatan pembangunan dan pemerintahan pada umumnya sangat penting ${ }^{17}$. Hal ini juga dimaksudkan sebagai wadah untuk saling mengenal antara satu dengan yang lainnya. Maka dapat dipahami bahwa seorang pemerintah/penguasa yang menegakkan keadilan berarti ia telah menjalankan jabatan yang di berikan dengan sebaik-baiknya. Setiap kekuasaan yang dilaksanakan dengan adil bagi setiap orang termasuk si penguasa/pemerintah itu sendiri. Sebaliknya, apabila kekuasaan itu diterapkan secara dzalim (tiran, diktator, otoriter atau absolut) maka kekuasaan itu akan menjadi bumerang dalam bentuk bencana,

17 Tutik, Titik Triwulan. Pokok-Pokok Hukum Tata Negara Indonesia Pasca Amandemen UUD 1945. Cet. I; Cerdas Pustaka, 2008, Jakarta, hal 3. 
malapetaka yang akibatnya tidak akan terlepas dari si penguasa/pemerintah itu sendiri ${ }^{18}$.

Penelitian yang dilakukan oleh Sri Nurhayati, Agus Riwanto dan Isharyanto (2018) menjelaskan salah satu penghambat tugas dari BPD adalah bahwa lembaga-lembaga desa yang berwenang menjalankan dan membentuk Perdes, yakni Kades dan BPD belum mampu merumuskan Rancangan Perdes (Raperdes) yang dapat diterima dari sisi teknik perancangan peraturan perundang-undangan (legal drafting). Bahkan, sebagian besar belum tahu secara persis apa itu Peraturan Desa dan bentuk-bentuknya ${ }^{19}$.

Sedangkan penelitian yang dilakukan Al Mukri, Alfiandra, Sri Artati Waluyati ada beberapa faktor yang menghambat kinerja dari BPD yaitu faktor sumber daya manusia dari BPD yang tidak menguasai kemampuan menyusun peraturan desa, faktor inovasi yang meliputi tidak terdapat cara-cara baru dari BPD dalam menggali aspirasi masyarakat yang dilakukan secara kreatif dan menarik bagi masyarakat. Faktior ketiga adalah faktor adaptasi organisasi yang meliputi kurangnya sosialisasi pengurus BPD kepada masyarakat pada setiap tahap penyusunan peraturan desa ${ }^{20}$.

Kondisi sosial masyarakat yang masih belum percaya dengan adanya BPD, masyarakat masih merasa bahwa BPD belum benar-benar menjalankan tugasnya sesuai dengan harapan dari masyarakat serta sumber daya anggota BPD yang masih relatif rendah, terbatasnya

18 Awaeh, Johanis \& Kairupan. Peranan Badan Permusyawaratan Desa (BPD) dalam Penyelenggaraan Pengawasan Pemerintahan (Studi di Desa Sereh 1 Kecamatan Lirung Kabupaten Talaud. JURNAL EKSEKUTIF. Vol. 1 No 1, 2017, Program Studi Ilmu Pemerintahan Universitas Sam Ratulangi, Manado, hal 9.

${ }^{19}$ Sri Nurhayati, Agus Riwanto dan Isharyanto, Faktor Pendukung Dan Penghambat Peran Badan Permusyawaratan Desa Tawengan Dalam Proses Penetapan Peraturan Desa, Jurnal Hukum Dan Pembangunan Ekonomi Vol 6 No 2, Fakultas Hukum Universitas Sebelas Maret, 2018, Surakarta.

${ }^{20} \mathrm{Al}$ Mukri, Alfiandra, Sri Artati Waluyati, Faktor-Faktor Penyebab Belum Efektifnya Peran Badan Permusyawaratan Desa Dalam Penyusunan Peraturan Desa (Studi Kasus Di Desa Seri Kembang Ii Kecamatan Payaraman Kabupaten Ogan Ilir), Jurnal Bhinneka Tunggal Ika, Vol 5, No 1 FKIP Universitas Sriwijaya, 2018, Palembang, hal 13-23. http://dx.doi.org/10.36706/jbti.v5i1.7895 
jumlah anggaran dari pemerintah, Sumber Daya Manusia (SDM) perangkat desa Labuang Kecamatan Namrole Kabupaten Buru Selatan yang masih rendah dan sebagian perangkat desa maupun anggota BPD yang tidak secara aktif mensosialisasikan sebuah peraturan desa. Penelitian ini juga menemukan kurang difungsikannya kantor desa, tidak ada ruangan kerja BPD dan minimnya sumber daya manusia.

Berdasarkan hasil kajian dari penelitian ini memberikan erekomendasikan antara lain : (a) Meningkatkan kinerja BPD dalam melaksanakan tugas dan fungsinya, khususnya yang terkait dengan fungsi kontrol dan fungsi pengawasan terhadap pemerintah desa yang sesuai dengan keinginan dan aspirasi masyarakat; (b) Perlu dikembangkan lebih intensif komunikasi yang sehat, baik secara horizontal maupun vertikal dan komunikasi yang mengedepankan kepentingan masyarakat di atas kepentingan pribadi atau kelompok; (c) Perlu adanya masukan dari lembaga-lembaga yang bersifat membangun dan meningkatkan kinerja BPD demi tercapainya kemajuan, kesejahteraan dan kemakmuran masyarakat; (e) Perlu mempertahankan kebersamaan antara BPD, Pemdes, LPMD dan masyarakat dalam menyikapi program yang diharapkan pemerintah dan keinginan masyarakat sesuai dengan kemajuan jaman; dan (e) Masyarakat harus lebih aktif dan kritis di dalam menyikapi berbagai kebijakan dan produk hukum yang dihasilkan oleh BPD, serta di dalam proses penyusunan kebijakan.

\section{PENUTUP}

Badan Permusyawaratan Desa (BPD) di Desa Labuang Kecamatan Namrole Kabupaten Buru Selatan belum dapat menjalankan perannya secara optimal disebabkan sumber daya manusia anggota BPD masih rendah, khususnya dalam bidang pendidikan sehingga dalam menjalankan peran dan fungsinya BPD tidak mengerti apa yang harus dilakukan terkait dengan fungsi kontrol dan fungsi pengawasan yang menjadi kewenangannya dalam mengontrol dan 
mengawasi kinerja pemerintah desa/kepala desa. Faktor-faktor yang menghambat peran Badan Permusyawaratan Desa (BPD) dalam penyelenggaraan pemerintahan di desa labuang, antara lain : peran BPD tidak efektif disebabkan oleh anggaran operasional BPD sangat minim, sarana dan prasarana BPD sangat tidak memadai dan tidak memiliki kantor sendiri sehingga dalam menjalankan tugasnya hanya numpang di kantor desa, anggota BPD yang tidak secara aktif mensosialisasikan sebuah peraturan desa, minimnya sumber daya manusia anggota BPD.

\section{DAFTAR PUSTAKA}

\section{Buku}

Bachsan Mustafa, SH. Sketsa Dari Tata Hukum Indonesia. CV Amriko. 1982. Bandung.

Beratha, N. Masyarakat Desa dan Pembangunan Desa. Ghalia Indonesia, 1992. Jakarta.

Saldi Isra. Pergeseran Fungsi Legislasi : Menguatnya Model Legislasi Parlementer Dalam Sistem Presidensial Indonesia, Raja Grafindo Persada, 2010, Jakarta.

Packer, Herbert L. The Limits of the Criminal Sanction, Stanford University Press, 1968, California.

Tahir Azhari, Muhammad. Negara Hukum, Prenada Media, 2004, Jakarta.

Tutik, Titik Triwulan. Pokok-Pokok Hukum Tata Negara Indonesia Pasca Amandemen UUD 1945. Cet. I, Cerdas Pustaka, 2008, Jakarta.

\section{Jurnal}

Ahadi Fajrin Prasetya. Peran Badan Permusyawaratan Desa dalam Mewujudkan Pembentukan Peraturan Desa yang Partisipatif di Kabupaten Lampung Timur. Fiat Justisia, Vol. 10 No 3. 2016, Universitas Bandar Lampung, Lampung. https://doi.org/10.25041/fiatjustisia.v10no3.785

Al Mukri, Alfiandra, Sri Artati Waluyati, Faktor-Faktor Penyebab Belum Efektifnya Peran Badan Permusyawaratan Desa Dalam Penyusunan Peraturan Desa (Studi Kasus Di Desa Seri Kembang Ii Kecamatan Payaraman Kabupaten Ogan Ilir), Jurnal Bhinneka Tunggal Ika, Vol 5, No 1, FKIP Universitas Sriwijaya, 2018, Palembang, hal 13-23. http://dx.doi.org/10.36706/jbti.v5i1.7895

Awaeh, Johanis \& Kairupan. Peranan Badan Permusyawaratan Desa (BPD) dalam Penyelenggaraan Pengawasan Pemerintahan (Studi di Desa Sereh 1 Kecamatan Lirung Kabupaten Talaud. JURNAL EKSEKUTIF. 
Vol. 1 No 1, 2017, Program Studi Ilmu Pemerintahan Universitas Sam Ratulangi, Manado.

Darmini Roza, Laurensius Arliman S. 2017. "Peran Badan Permusyawaratan Desa (BPD) dalam Pembangunan Desa dan Pengawasan Keuangan Desa" PJIH: Jurnal Padjajaran Ilmu Hukum, Vol. 4 No 3. 2017, Universitas Padjajaran, Bandung, Bandung. https://doi.org/10.22304/pjih.v43.a10

Kursahandjani. Implikasi UU No. 6 Tahun 2014 tentang Desa terhadap Penyelenggaraan Pemerintahan Desa. Jurnal Ilmiah Ilmu Pemerintahan, Vol. 2 No 1, 2016, Jurusan Ilmu Pemerintahan Fakultas Ilmu Sosial dan Ilmu Politik, Universitas Diponegoro, Semarang. https://dx.doi.org/10.14710/jiip.v2i1.1635

Masuara Rico. Pelaksanaan Fungsi Badan Permusyawaratan Desa (BPD) dalam Penyelenggaraan Pemerintahan Desa (Suatu Studi di Desa Bolangitang Satu Kecamatan Bolangitang Barat Kabupaten Bolaang Mongondow Utara). Jurnal POLITICO, Jurnal Ilmu Politik, Vol. 3 No 1, 2014, Universitas Sam Ratulangi, Manado.

Ngarsiningtyas dan Walid. "Peran Badan Permusyawaratan Desa dalam Penyusunan dan Penetapan Peraturan Desa" JPPUMA: Jurnal Ilmu Pemerintahan dan Sosial Politik UMA, Vol. 4 No 2. 2016, Universitas Medan Area, Medan. https://doi.org/10.31289/jppuma.v4i2.454

Rodhiah \& harir. Peranan Badan Permusyawaratan Desa (BPD) dalam pembentukan peraturan desa di Desa Krandon Kecamatan Guntur Kabupaten Demak. Jurnal Pembaharuan Hukum, Vol. 2 No 2. 2015, Universitas Islam Sultan Agung Semarang, Semarang.

Sam, Belinda, Risman Iye, Mirja Ohoibor, M. Chairul Basrun Umanailo, M. Rusdi, A. B. D. Rahman, and Ibnu Hajar. "Female Feminism in the Customary Island of Buru." Int. J. Sci. Technol. Res Vol. 8 No. 8 , 2019, International Journal of Scientific \& Technology Research, New Delhi.

Sri Nurhayati, Agus Riwanto dan Isharyanto, Faktor Pendukung Dan Penghambat Peran Badan Permusyawaratan Desa Tawengan Dalam Proses Penetapan Peraturan Desa, Jurnal Hukum Dan Pembangunan Ekonomi Vol 6 No 2, Fakultas Hukum Universitas Sebelas Maret, 2018, Surakarta.

Susiati, Susiati, Risman Iye, and L. O. A. Suherman. "Hot Potatoes Multimedia Applications in Evaluation of Indonesian Learning In SMP Students in Buru District." ELS Journal on Interdisciplinary Studies in Humanities Vol. 2 No. 4, 2019, Universitas Hasanuddin Makassar, Makassar. http://doi.org/10.34050/els-jish.v2i4.8455

Susanti \& Setaji,"Penguatan Peran Badan Permusyawaratan Desa (Bpd) dalam Mendukung Sinergitas Penyelenggaraan Pemerintahan Desa Di Kabupaten Semarang Tahun 2018. INTEGRALISTIK. Journal UNNES, Vol. 29 No 2. 2018, Universitas Negeri Semarang, Semarang. https://doi.org/10.15294/integralistik.v29i2.17947 
Tegar."Peran Badan Permusyawaratan Desa Dalam Penyelenggaraan Pemerintahan Desa (Studi Kasus Di Desa Sidodadi Kecamatan Taman Kabupaten Sidoarjo). Publica: Jurnal Ilmu Administrasi Negara, Vol. 4 No 8. 2016, Universitas Negeri Semarang, Semarang.

\section{Peraturan perundang-undangan}

Peraturan Pemerintah No. 6 Tahun 2014 tentang Desa

Peraturan Menteri Dalam Negeri No 110 Tahun 2016 Tentang Badan Pemusyawartan Desa

Peraturan Daerah Kabupaten Buru Selatan No 24 tahun 2011Tentang Pembentukan, Penghapusan, Penggabungan Desa Dan Perubahan Status Desa Menjadi Kelurahan.

Undang-Undang Dasar Negara Republik Indonesia Tahun 1945. Jakarta: Sekretariat Jenderal dan Kepaniteraan Mahkamah Konstitusi Republik Indonesia. Undang-Undang No. 9 Tahun 2015 tentang Pemerintahan Daerah. Jakarta: Sekretariat Negara Republik Indonesia. 